\title{
PRODUCTION OF BIODIESEL FROM CORN COB
}

\author{
BALOGUN, Ayodeji Timothy \\ B-Tech (Chemical Engineering) FUT, Minna \\ M-Tech (Chemical/Petrochemical Engineering) RSU \\ PG.2017/00489
}

\begin{abstract}
The use of an agricultural waste product corn cob for the production of biodiesel has been performed. Biodiesel was obtained by extraction of the corn cob and used to produce biodiesel by transesterification, using a mixture of methanol and potassium hydroxide (methanoxide). The produced biodiesel was characterized, and the results of the physiochemical properties were as follows: viscosity, density, flash point, $\mathrm{pH}$ and refractive index. These values compare favourably with corresponding values of standard biodiesel.
\end{abstract}

KEYWORDS: Biodiesel, corn cob, transesterification, methanoxide. 


\section{INTRODUCTION}

\subsection{Background of Study}

The petroleum-based economy has been playing a key role in the development of countries. Since the Industrial Revolution, fossil fuels have leveraged the growth and progress of nations, reaching a vital function in 'our energy-dependent society. Nevertheless, the uses of fossil fuels have several disadvantages that have become strongly evident. Global warming, pollution, glacial melting, petroleum spills and gas leaks, contamination and health problems are just few of the countless problems associated with burning petroleum, natural gas and coal. Conversely, a promising area getting stronger is developing fuels, chemicals and materials in a bio-sustainable way. The bio economy, a bio-based platform economy, is enlightening the challenge but has a long way to go through before achieving its final goal of replacing petroleum products and non-renewable energy sources. Biomass has the potential to strongly contribute to the bio economy, supplying a myriad of ingredients and energy alternatives yet to be discovered Biomass is abundant and can be produced and harvested from crops, forest, animal wastes, etc. Biomass, as defined by Perlack et al., (2005) is "Any organic matter that is available on a renewable or recurring basis, including agricultural crops and trees, wood and wood residues, plants (including aquatic plants), grasses, animal manure, municipal residues, and other residue materials" and is generally "produced in a sustainable manner from water and carbon dioxide by photosynthesis."

\section{History of Biodiesel}

The concept of using vegetable oil as an engine fuel likely dates to when Rudolf Diesel (1858-1913) developed the first engine to run on peanut oil, as he demonstrated at the world exhibition in Paris in 1900. Rudolf Diesel firmly believed the utilization of a biomass fuel to be the real future of his engine He wanted to provide farmers the opportunity to produce their own fuel. In 1911, he said "The diesel engines can be feed with vegetable oils and would help considerably in the development of agriculture of the countries which use it."

"The use of vegetable oils for engine fuel may seem insignificant today. But such oils may become, in the course of time as important as the petroleum and coal tar products of the present time.” Rudolf Diesel (1912).

\section{What is Biodiesel}

Biodiesel is alternative liquid fuel (similar to conventional fossil/petroleum diesel) derived from vegetable oils and fats, which has similar combustion properties to regular petroleum diesel fuel. Biodiesel can be produced from straight vegetable oil, animal fat, tallow and waste cooking oil.

Biodiesel is biodegradable, non-toxic, and has significantly fewer emissions than petroleum based diesel when burned.

\section{Benefits/Advantages of Biodiesel}

Biodiesel is bio renewable. Feedstock's can be renewed one or more times in a generation. Biodiesel is carbon neutral plants use the same amount of $\mathrm{CO} 2$ to make the oil that is released when the fuel is burned. 
Biodiesel is biodegradable and completely non-toxic, meaning spillage represents far less risk than petroleum diesel spillage

The use of biodiesel can extend the life of diesel engines because it is more lubricating and furthermore, power output is relatively in affected by biodiesel.

\subsection{Aim of the Study}

To produce a biodiesel which can substitute fossil fuel from corn cob - a corn waste material that liters the environment.

\subsection{Objective of the Study}

The aim stated above will be achieved following these steps

1. Obtaining and processing raw materials

- Obtain the corn cobs

- Drying the corn cob

- Crushing the corn cob

2. Storage of raw materials

3. Biodiesel production

- Extraction

- Trans-esterification

4. Biodiesel characterization

Determination of physical and chemical properties

- Density

- Viscosity

- Refractive index

- Flash point

5. Comparison of biodiesel with conventional fossil fuels

6. Test running.

\subsection{Scope of the Study}

This work is focused on the use of waste corn cob, which will serve as one of the major material for the production of biodiesel. It would highlight the basic factors necessary for cultivation, consumption, assembling of the waste com cobs, storage processing of corn cobs and the chemical processes involved.

\section{$1.4 \quad$ Justification of the Study}

Since corn cob is a waste product from corn, it implies that there would be no added cost apart from cultivation of com and it goes a long way to environmental sanitation and green recycling, thus keeping the environment clean and safe.

The depletion in fossil fuel reserves had led to the global push for innovative researches in renewable sources of energy. This is because the natural sources of energy are depleting while the demand for energy is rising astronomically. 
Hence, this research is intended to produce biodiesel which is very useful and of high demand in the energy sector from a renewable material (waste corn cob oil).

\section{LITERATURE REVIEW}

Only after times of scarcity and energy independence constraints, such as OPEC's embargo in 1967, the oil crisis in 1973, the rise in oil price in 2008, etc. is when we realize how brittle and reliant on petroleum our society is, with the resulting interest in finding and exploring alternative energy avenues. Many countries have taken the initiative to walk the path of substitutes, and breaking the scheme of fossil energy's monopoly Bourne, (2007) emphasized that current replacement of conventional fuels by alternatives are small but highly promising. He claims that at most $12 \%$ of gasoline and $6 \%$ of the diesel demand (as to that particular year) could be supplied if all the com and soybean cropped in the US was to be processed into biofuels However, the information only referred to conventional food crops that are now being routed towards liquid fuels. But prospective technology breakthroughs could increase by many folds the current biofuel production threshold. In this respect, biomass has been a leading candidate as a substitute for liquid fuel transportation The National Renewable Laboratories in Golden, Colorado, estimate a maximum conversion rate of corn crop residues of 113 gallons of ethanol per dry metric ton (NREL, 2007); however, Reeder and Li (2010) estimate that feasible carbohydrate fermentation will yield around $73 \mathrm{gal} / \mathrm{dry}$ ton. The Billion Ton Study presented by the U.S. Department of Agriculture showed that the U S could produce 1.3 billion tons of feedstock for bioethanol conversion, reaching approximately 90 billion gallons of ethanol (Perlack, et al., 2005). Thermochemical processes could greatly overcome fermentation yields, but still, biomass conventional processed could replace more than half of the transportation fuel currently burned each year.

The production of biodiesel from waste com cob is quite interesting Bio-energy is one of the so-called renewable energy, it is contained in living biological organisms. Bio-energy is obtained from organic matters either directly or indirectly from plants or indirectly from industrial, commercial, domestic or agriculture products and waste. The use of bio-energy is generally classified as a carbon-neutral process because the carbon dioxide released during the generation of energy is balanced.

The term bio-energy really covers two areas which are;

- Bio-fuel; which is the transformation of plant material into liquid fuel.

- Biomass; where solid plant materials are burnt in a power plant and this process creates energy.

\subsection{Corn Cob Commercial Utilization}

Corn cobs are an abundant source of thermal energy for producing heat, power, fuels and many chemicals too (Kaliyan \& Vance, 2008). Historically, corn cobs have been used for whole array of different products, from small modifications of its original physical and chemical properties to highly industrialized goods. For instance, The Andersons Inc. located in Indiana has long processed cobs for many agrichemical and commercial applications such as abrasives, absorbents, activated carbon, asphalt shingle and roofing, chemical waste absorbent, concrete additive, feedstock for petrochemical industry (xylitol, furfural, oxalic 
acid), fermentation substrates, fertilizer diluents, food fiber source, carriers for chemicals such as herbicide, insecticide and pesticides, insulating materials, plastic extenders, and many more products (Anderson Inc). Recently, studies are exploring the use of com cob for its energy content mainly for ethanol fermentation, co-firing and as a feedstock in thermochemical conversion technologies, thus potentially broadening the demand and importance of this so called "farm residue".

Further work to refine specific systems of utilizing corn cobs would be of great benefit to agriculture, finding markets and alternative uses of material for farmers' profits. Economic comparison between storage options and deterioration during storage will influence cobs value and cost of storage In energy systems, cob costs need to include dry matter loss and changes of moisture content, whereas if the cobs are being stored for chemical production then mass loss but even more important, compositional changes will be a factor determining cob storing and handling Ethanol sector has rapidly grown in the last decade, reaching close to 11 billion gallons in 2009 (Renewable Fuel Association). Private and public sector are strongly supporting the development of this renewable fuel as it has a number of advantages in terms of social, economic and environmental aspects. Currently, ethanol is mainly produced from the com kernel, but it is envisioned to be also produced from lignocellulosic, such as corn Stover, switch grass, woody biomass, etc. The new regulations proposed by Environmental Protection Agency establishes the production of 36 billion gallon of renewable fuels, in which 16 billion gallons will come from cellulosic biofuels, in which the cellulose fermentation pathway would be one of the major contributors (EPA, 2009).

Decades ago, com cobs have been used for drying seed and more recently as an energy source. The seed industry and farmers tried to benefit from cobs barely used before and find a new use for the material that could let them save money on drying operations (Dahlberg, 1977). In the past, many cob burners and gasifiers were proposed to be used The energy content of com cobs is around $18.4 \mathrm{MJ} / \mathrm{kg}$ (high heating value), comparable to other cellulosic materials such as wood, and even cobs have 6\% more energy than shelled com and $11 \%$ more than cornstalks (Dahlberg, 1977). He also claimed that from kernel with 35\% moisture and $66 \%$ efficient drier, there is enough energy in the cob to dry the corresponding kernels under average corn-belt drying conditions. Many seed plants had implemented different types of burners, and have successfully decreased drying expenses; however, problems in cob handling and burners prevented the technology from being extensively adopted. Main problems were focused on material handling, particulate matter emission (very fine ash). Also, corrosion caused by water vapor in combination with sulfur and chlorides producing acids, difficulties for temperature control, greater maintenance required than conventional natural gas burners, and slag formation at high temperature $\left(950^{\circ} \mathrm{C}\right)$ where minerals components melt and solidify as green glasslike substance These problems highlighted by Dahlberg (1977) which prevented cobs from replacing natural gas for seed companies in drier facilities. Furthermore, natural gas could be easily hooked on and it is a relatively cheap source of energy. Other problems associated with this types of seed dryers were tar material condensation at low temperature (below $300^{\circ} \mathrm{C}$ ), which would plug pipes, fans, burners and valves. Approaches to solving tar condensation were to burn the producer gas at high temperature before it condenses, use down-draft gasifiers in order to oxidize and burn tars, or cool down the gas to condense the tar and bum the gas once it has been cleaned. A latter more sophisticated approach to solve many of the problems with cobs burners was the use of gasifiers or pyrolysis units to produce low energy gas (in comparison to methane). If utilized within short distances, low BTU values for the gas wouldn't be detrimental; but it 
is still a problem that adds to the cost (heat content of $150 \mathrm{BTU} / \mathrm{cu} \mathrm{ft}$ vs natural gas 1000 BTU/cu ft). Morey, et al.,(1984) proposed that a farmer with 200 ha requires approximately 50 tons of cobs to dry his corn with average yielding. Cob piles in farm drying operations are a feasible alternative system to be used in the same season or, depending on the conditions, dried and stored for later use.

\subsection{What are Fossil Fuels}

Fossil fuels are fuels formed by natural processes such as anaerobic decomposition of buried dead organisms such as plants and animals that has spent millions of years some time exceeds 650 million years under ground in extreme conditions and so it has changed significantly and its energy value is thus concentrated. The use of fossil fuels raises serious environmental concerns. The burning of fossil fuel fuels produces around 21.3 billion tones (21.3 gigatonnes) of carbon dioxide $\left(\mathrm{CO}_{2}\right)$ per year. Carbon dioxide is one of the greenhouse gases that enhances radiation, forcing and contributes to global warming, causing the average surface temperature of the earth to rise in response, which the vast majority of climate scientists agree will cause major adverse effects. A global movement towards the generation of renewable energy is therefore underway to help reduce global greenhouse gas emission

Bio fuels like corn cobs would supply this renewable energy needed.

\subsection{Why the Use of Biodiesel}

For various reasons, biodiesel is essential and economical. In the most general sense biodiesel refers to any diesel fuel substitute derived from renewable biomass. More specifically, biodiesel is defined as oxygenated, sulphur-free, biodegradable, nontoxic and eco-friendly alternative diesel oil. Chemically, it can be defined as a fuel composed of mono-alkyl esters of long chain fatty acids derived from renewable sources such as vegetable oil, animal fat and the used cooking oil. For it to be considered as viable transportation fuel it must meet stringent quality standard like ASTM-American society for testing and materials (International Energy Agency 2008).

One popular process for producing biodiesel is by transesterification Biodiesel is made from a variety of natural oils such as soybean, rapeseed, coconut, sunflower oil and even the recycled cooking oil. Rapeseed oil dominates the growing biodiesel industry in Europe while in the United States biodiesel is made from soybean oil because more of it is grown there. The injection and atomization characteristics of the vegetable oils are significantly different than those of the petroleum derived diesel fuel mainly as the result of their high viscosities. Modem diesel engines have fuel injection system that is sensitive to viscosity change One way to avoid these problems is to reduce fuel viscosity of vegetable oil in order to improve its performance. The conversion of vegetable oils into biodiesel is an effective way to overcome all the problems associated with the vegetable oil Dilution, micro- emulsification, pyrolysis and transesterification are four basic techniques applied to solve the problems encountered with high fuel viscosity. Transesterification is the most common method and this leads to mono-alkyl esters of vegetable oil and fats called biodiesel when used for fuel purposes. The methyl- ester produced by transesterification of vegetable oil has a high cetane number, low viscosity and improved heating value compared to those of the pure vegetable oil which result in shorter ignition delay and longer combustion duration and hence low particulate emission. 


\subsection{What are Corn Cobs}

Corn cobs are primarily considered because they are waste materials and as such environmental waste pollution is controlled.

A corn cob is the central core of a maize ear. It is the part of the ear on which the kernels grows. Corn (zea mays) is a popular feed stock for ethanol production due to its abundance of conversion to ethyl alcohol (ethanol). Corn and other starch grains haven converted into ethanol for thousands of years, yet only the past century has its use as fuel greatly expanded. Conversion includes grinding, cooking with enzymes, fermentation with yeast, distillation to remove water. For fuel ethanol, two more steps are included to molecular sieve to remove the last of the water denaturing to make the alcohol undrinkable.

Although bio fuels still release carbon dioxide into the atmosphere but since corn cob which is a plant are used, it was extracted from the atmosphere through photosynthesis, and will be reused by future crops. By limiting the amount of carbon moving from the underground to the atmosphere, the idea is to reduce the intensity of global warming.

\subsubsection{Other Applications for Corn Cob}

- Industrial source of furfural (i.e. organic compound derived from a variety of agricultural by product).

- Fiber in animal feed for ruminant livestock (despite nutritional values).

- Livestock bedding-cobs absorb moisture and provide complaint surface.

- Raw materials for corn cob pipes

- Fuel- corn cob may be burned to produce heat

- Charcoal production.

\subsection{Advantages of Corn Cob}

The advantages of using bio-oil (obtained from corn cob) to produce diesel fuel are:

- Portability

- ready availability

- renewability

- higher heat content(about $88 \%$ of diesel fuel)

- lower sulphur content

- lower aromatic content

- biodegradability

\subsection{Disadvantages of Bio-Oil as Biodiesel Fuel}

The disadvantages of using vegetable oil as biodiesel fuel are:

higher viscosity

$>$ lower volatility

$>$ reactivity of unsaturated hydrocarbon chains

Bio-oils are liquid fuels from renewable sources; they do not over-burden the environment with emission bio-oils have potential for making marginal land productive by their property of nitrogen fixation in the soil. Their production requires lesser energy input; they have 
higher energy content than other energy crop like alcohol; they have about $90 \%$ of the heat content of diesel and they have a favorable output/input ratio of about 2-4:1 for unirrigated crop production. Bio-oil combustion has a cleaner emission spectra and simpler processing technology. It should be noted that due to rapid decline in crude oil reserves, the use of biooil as diesel fuel is again promoted in many countries depending upon climate and soil conditions. Different nations are looking into different agricultural products for biodiesel, for instance soybean oil in United States, rapeseed and sunflower oil in the Europe, palm oil in Southeast Asia (mainly Malaysia and Indonesia), and coconut oil in Philippines are being considered as substitute for mineral diesel. An acceptable alternative fuel for engine has to fulfill the environmental and energy security needs without sacrificing operating performance Corn cob oil can be used when converted in compressed ignition engines through engine modifications and fuel modifications because vegetable oil in its raw form cannot be used in engines, it has to be converted to a more engine friendly fuel called BIODIESEL an alternative fuel for diesel engines.

\subsection{Transesterification of Bio-Oil (Corn Cob)}

\section{Making Biodiesel: Transesterification}

Transesterification of natural glycerides with methanol to methylesters is a technically important reaction that has been used extensively in the soap and detergent manufacturing industry worldwide for many years. Almost all biodiesel is produced in a similar chemical process using base catalyzed transesterification as it is the most economical process, requiring only low temperatures and pressures while producing a 98\% conversion yield. The transesterification process is the reaction of a triglyceride (fat/oil) with an alcohol to form esters and glycerol. A triglyceride has a glycerine molecule as its base with three long chain fatty acids attached The characteristics of the fat are determined by the nature of the fatty acids attached to the glycerine. The nature of the fatty acids can, in turn, affect the characteristics of the biodiesel.

During the esterification process, the triglyceride is reacted with alcohol in the presence of a catalyst, usually a strong alkaline like sodium hydroxide. The alcohol reacts with the fatty acids to form the mono-alkyl ester, or biodiesel, and crude glycerol. In most production, methanol or ethanol is the alcohol used (methanol produces methyl esters, ethanol produces ethyl esters) and is base catalyzed by either potassium or sodium hydroxide Potassium hydroxide has been found more suitable for the ethyl ester biodiesel production, but either base can be used for methyl ester production.

The figure below shows the chemical process for methyl ester biodiesel. The reaction between the fat or oil and the alcohol is a reversible reaction, so the alcohol must be added in excess to drive the reaction towards the right and ensure complete conversion. 


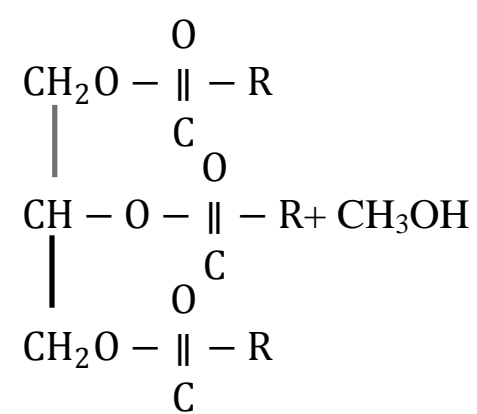

Glyceride

$$
\begin{aligned}
& \stackrel{\text { OH }}{\rightleftharpoons} \quad \begin{array}{c}
0 \\
\text { C }
\end{array} \\
& \text { Catalyst }
\end{aligned}
$$

Source: www.esru.strath.ac.uk/EandE/Web sites/02-03/biofuels/what biodiesel.htm

The products of the reaction are the biodiesel itself and glycerol. A successful transesterification reaction is signified by the separation of the methyl ester (biodiesel) and glycerol layers after the reaction time. The heavier co-product, glycerol, settles out and may be sold as is or purified for use in other industries, e.g. pharmaceutical, cosmetics, and detergents.

After the transesterification reaction and the separation of the crude heavy glycerin phase, the producer is left with a crude light biodiesel phase. This crude biodiesel requires some purification prior to use.

Biodiesel has a viscosity similar to petroleum diesel and can be used as an additive in formulations of diesel to increase the lubricity. Biodiesel can be used in pure form (B100) or may be blended with petroleum diesel at any concentration in most modern diesel engines. Biodiesel will degrade natural rubber gaskets and hoses in vehicles (mostly found in vehicles manufactured before 1992), although these tend to wear out naturally and most likely will have already been replaced with Viton type seals and hoses which are nonreactive to biodiesel. Biodiesel's higher lubricity index compared to petroleum diesel is an advantage and can contribute to longer fuel injector life.

Biodiesel is a better solvent than petroleum diesel and has been known to break down deposits of residue in the fuel lines of vehicles that have previously been run on petroleum diesel Fuel filters may become clogged with particulates if a quick transition to pure biodiesel is made, as biodiesel "cleans" the engine in the process. It is, therefore, recommended to change the fuel filter within 600-800 miles after first switching to a biodiesel blend.

Biodiesel is, at present, the most attractive market alternative among the non-food applications of vegetable oils for transportation fuels The different stages in the production of plant/seed oil methyl ester generate by-products which offer further outlets. Oil cake, the protein rich fraction obtained after the oil has been extracted from the seed, is used for animal feed. Glycerol, the other important by-product, has numerous applications in the oil and chemical industries such as the cosmetic, pharmaceutical, food, and painting industries. 


\section{Sustainability in Relation to Biofuels Production}

\section{Legislation}

Legislation and governmental policies are the key promoters of the production and use of biofuels. For example, in the European Union's regulation, Directive 2003/30/EC (2003) included the aim to cover a $5.75 \%$ share of transportation fuels bybiofuels or other renewable fuels by the year 2010. The target was increased by the Renewable Energy Directive (RED) to a $10 \%$ share of biofuels in the transportation sector by 2020 (Directive 2009/28/EC). Biofuels produced from lignocellulosic or nonfood cellulosic material, wastes or residues are counted as double share in comparison to biofuels produced from other sources. Further, the Fuel Quality Directive (FQD) sets the minimum quality requirements for transportation biofuels (Directive 2009/30/EC). The RED Directive takes into account sustainability by means of reduced emissions: a target for the minimum $35 \%$ reduction $(50 \%$ for new installations starting biofuel production in 2017 and 60\% for those starting in 2018) of greenhouse gas emissions as compared to fossil fuels is set. Three articles on sustainability are included in the Directive:

- Sustainability criteria for biofuels and bioliquids (Article 17)

- Verification and compliance with the sustainability criteria for biofuels and bioliquid (Article 18)

- Calculations of the GFIG impact of biofuels and bioliquids (Article 19)

The main requirements state that areas of high biodiversity and high carbon stock are not allowed to be used and sustainability of biofuels used in the EU should be checked by the Member States of the EU. The Directive also includes a methodology for GFIG emission calculations and default values for 22 biofuel production pathways. However, it focuses on environmental issues and there are no mandatory criteria for economic and social sustainability. There is also a voluntary certification system available to guarantee that biofuels are produced in a sustainable way and according to criteria set in the RED Directive. At the moment, 14 voluntary schemes applied in 27 EU Member States are recognised by the European Commission (European Commission, 2013).

The practical implementation of sustainability criteria is still in progress, but some standards are available. For instance, parts 1, 3 and 4 of the European Standard EN 16214 'Sustainably produced biomass for bioenergy applications' have been published recently, while parts 2 and 5 are not approved yet (CEN, 2013). In addition, an international standard ISO/CD 13065 'Sustainability criteria for bioenergy' is under development and expected to be published by April 2015 (ISO 2013).

\subsection{Environmental Benefits of Biodiesel Fuel}

Economic, environmental and social impacts: The main impacts connected to the production of biofuels are listed in Table.

It should be noted that regardless of their importance, the implemented legislation and standards drawn up by the EU do not include GHG emissions, land-use change issues or indirect effects, for example. 
Table 2.1: Positive and Negative Impacts Rotated to Biofuels Production (Heck, 2004).

\begin{tabular}{|c|c|c|}
\hline Aspects & Positive impacts & Negative impacts/risk \\
\hline Economic & $\begin{array}{l}\text { Regional added value by e.g. } \\
\text { generation of jobs, increased the } \\
\text { purchasing power and higher tax } \\
\text { incomes }\end{array}$ & $\begin{array}{l}\text { Low revenues if capital and } \\
\text { operation costs are high }\end{array}$ \\
\hline Environmental & $\begin{array}{l}\text { Reduced fossil fuel need, reduced } \\
\text { GHG emissions, less energy } \\
\text { consumption and waste generation } \\
\text { by advanced processing methods }\end{array}$ & $\begin{array}{l}\text { Direct/indirect land-use change } \\
\text { (LUC/ILUC), removal of } \\
\text { nutrients, water run-off, soil } \\
\text { erosion, decreased biodiversity, } \\
\text { use of toxic chemicals }\end{array}$ \\
\hline Social & $\begin{array}{l}\text { Improved energy security, increased } \\
\text { employment, development of rural } \\
\text { areas, education and training } \\
\text { opportunities, innovation and } \\
\text { knowledge potential }\end{array}$ & $\begin{array}{l}\text { Ethical issues: competing } \\
\text { demand with food usage (first- } \\
\text { generation feedstock safety of } \\
\text { employees }\end{array}$ \\
\hline
\end{tabular}

\subsection{Environmental Benefits of Biodiesel in Comparison to Petroleum Based Fuel}

Biodiesel is the only alternative fuel to have fully completed the health effects testing requirements of the clean air Act. The use of biodiesel in a conventional diesel engine results in substantial reduction in the production of unburned hydrocarbons, carbon monoxide, and particulate matter compared to emission from diesel fuel. In addition, the exhaust emissions of sulphur oxides and sulfates (major components of acid rain) from biodiesel are essentially eliminated compared to that produced from the conventional diesel. The use of biodiesel results in a substantial reduction of unburned hydrocarbons. Emission of nitrogen oxides are either slightly reduced or slightly increased depending on the cycle of the engine and testing method used Based on engine testing, using the most stringent emissions testing protocols required by Environmental Protection Agency (EPA) for certification of fuels or fuel additives in the US, the overall ozone forming potential of the speculated hydrocarbon emission from biodiesel was nearly 50 percent less than that measured for diesel fuel.

- Carbon monoxide emissions are reduced to about 50\% and carbon dioxide to about $78 \%$ overall based in the fact that the carbon comes already present in the Earth's atmosphere, not from its crust, as in petro diesel

- Fewer aromatic hydrocarbons are present; 56\% reduction in benzofluoranthene and $71 \%$ reduction in benzopyrenes.

- Particulate emissions are reduced by up to $65 \%$, leading to reduced cancer risks of up to $94 \%$ according to test sponsored by the Department of Energy.

- Its higher cetane rating than petro diesel causes more rapid ignition when injected into the engine. It also has the highest energy content of any alternative fuel in its pure form (Pure Biodiesel B100).

- Biodiesel is biodegradable and non-toxic-tests sponsored by the United States Department of Agriculture confirm biodiesel is less toxic than table salt and biodegrades as quickly as sugar.

- Pure biodiesel (B100) can be used in any petroleum diesel engine, though it is more commonly used in lower concentrations. The recent mandates for ultra- low sulphur petro diesel make it necessary to use additives to increase lubricity and flow properties, so biodiesel is an obvious choice. Even the formulation $2 \%$ biodiesel and 
98\% petroleum diesel (B2) is capable of restoring lubricity to the fuel $5 \%$ biodiesel and $95 \%$ petroleum diesel (B5) is often used in snow removal equipment and other municipal systems.

Biodiesel is less flammable than gasoline or petro diesel. Its flash point $\left(>150^{\circ} \mathrm{C}\right)$ is much higher than that of petroleum diesel $\left(64^{\circ} \mathrm{C}\right)$ or gasoline $\left(-45^{\circ} \mathrm{C}\right)$. (Marshall Wyatt, Biofuel the car fuel 2006).

\subsection{Some Challenges for Using Biodiesel Fuel}

- Biodiesel was higher nitrogen oxide $\mathrm{NO}_{\mathrm{x}}$ emissions than petro diesel. The higher $\mathrm{NO}_{\mathrm{x}}$ emission may be due to the higher cetane rating and oxygen content of the fuel, so that atmospheric nitrogen is oxidized more readily. Catalytic converters and properly turned engines can reduce this emission.

- While the flash point of biodiesel is higher than that of gasoline or petro diesel, its gel point varies depending on the ester composition. Most biodiesel has higher gel and cloud point than that of petro diesel. This requires the heating of storage tanks, especially in cooler climates.

- Water contamination; Biodiesel is hydrophilic because of its oxygen content that permits hydrogen bonding of water molecules Water that is not removed during processing or present from storage tank condensation causes problems because:

- $\quad$ It reduces the heat of combustion of the fuel leading to more smoke harder starting and less power

- $\quad$ It leads to corrosion of vital fuel system components: fuel pumps, injector pumps, fuel lines etc.

- $\quad$ It freezes to form ice crystal near $0^{0} \mathrm{C}\left(32^{0} \mathrm{~F}\right)$ which are sites for gel formation of the fuel, decreasing its flow properties.

The growth of microbe colonies, which can plug up a fuel system, is increased by water presence. This is an ongoing problem for biodiesel users with heater fuel tanks.

\section{Current Work to be Done}

This project is meant to improve the production rate of biodiesel produce from the Waste Corn Cob Oil. Research shows that billions of corns are cultivated every year, and the waste cobs are littered around every corner of our environment around the world mainly from streets to towns and markets these wastages can be used to produce biodiesel rather than disposing it, and causing environmental pollution and hazard.

\section{MATERIALS AND METHODOLOGY}

In the production of biodiesel from corn cob, various steps, processes, equipment and phases are involved.

In theory the steps are categorized into two different phases.

1. Physical Phase

2. Chemical Phase 
In the physical phase the collection of raw materials includes cultivation, harvesting and storage of corn cobs. The equipment involved in the physical stage are: harvester, towed wager, modified chopper, a blower and corn cob.

In the chemical phase, the corn cob is subjected to three chemical processes which are extraction, distillation and transesterification. The materials involved in this chemical phase are: a solid liquid extraction apparatus, a simple distillation apparatus, heating mantle, conical flask, graduated syringe, a beaker, methanol, isopropyl alcohol, phenolphthalein indicator, potassium hydroxide hexane, hydrochloric acid, filter paper.

\subsection{Experimental Procedure \\ 3.1.1 Raw Material Preparation}

The corn cob was obtained from local farmers in Ogbogu Community in ONELGA, Rivers State. It was dried with sunlight for about 21 days, and then crushed with a crushing machine to very fine particles.

The chemicals used for this experiment were gotten from a chemical shop at Ojoto mile 2, Port Harcourt and the Department of Chemical/Petrochemical laboratory of the Rivers State University, Port-Harcourt.

\subsubsection{Extraction of Bio-Oil from Corn Cob}

The extraction process is the same thing as reflux process.

The solid material (com cob) was measured into a thimble (extraction bag) and weighed. The thimble was placed inside the soxhlet (apparatus) and then fixed to a distillation flask. A condenser was also fitted at the top of the soxhlet, and water was connected to the outlet and inlet of the condenser. The extraction solvent (hexane) was measured into the distillation flask. The whole setup was placed on a heating mantle and then heat was generated (using an electric cooker) into the system to enable the vapor go up to the thimble and also comes down after being condensed. The oil was carefully removed and taken for distillation. The whole set up used for the extraction process is called the solid liquid extraction apparatus as shown in Figure 3.1 below. 


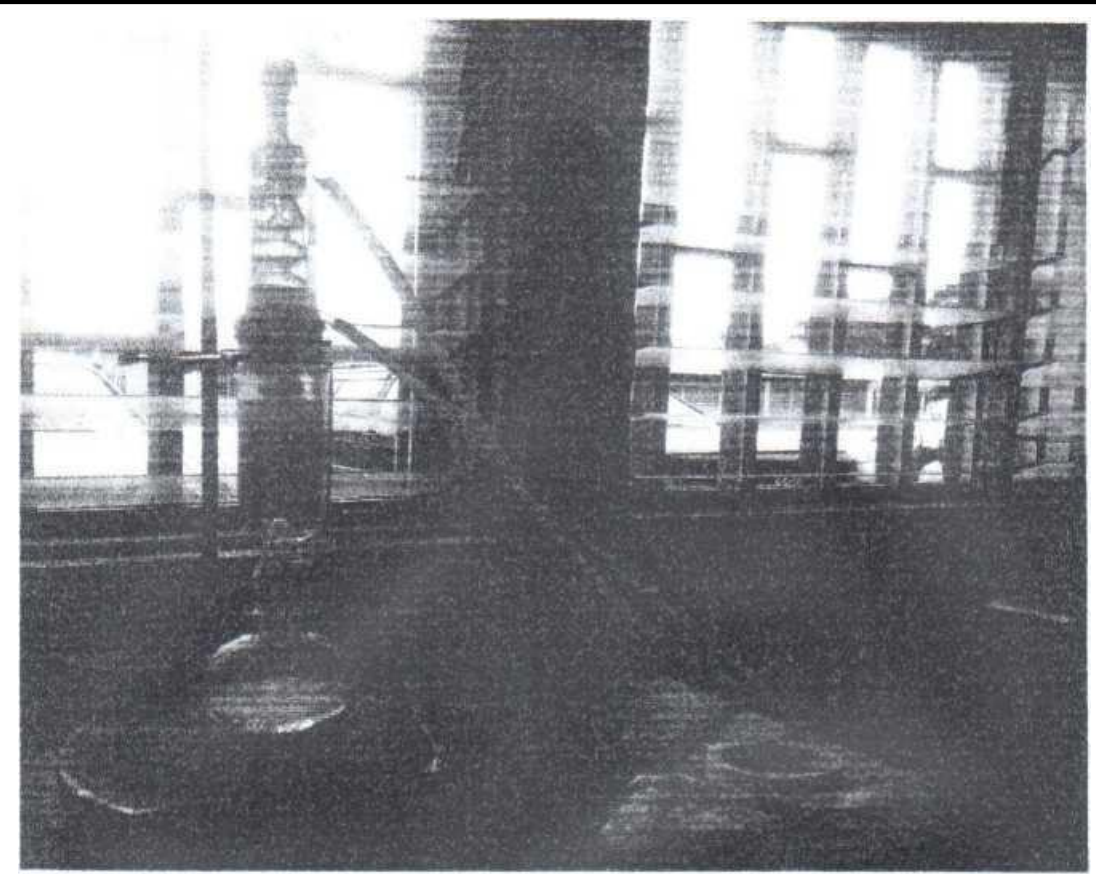

Figure 3.1: Solid Liquid Extraction Apparatus

\subsubsection{Distillation Process}

A simple distillation apparatus was setup as shown in Figure 3.2. The extracted mixture of oil and hexane solvent was measured into the distillation flask. The setup was placed on a heating mantle and then heat was generated (using an electric cooker) to enable the separation of the lighter component from the heavier component (solvent from oil). The lighter component (hexane) evaporates and leaves the flask while the heavier component (oil) remains at the bottom of the distillation flask. The oil was carefully collected and analyzed for free fatty acid before being used for the production of biodiesel.

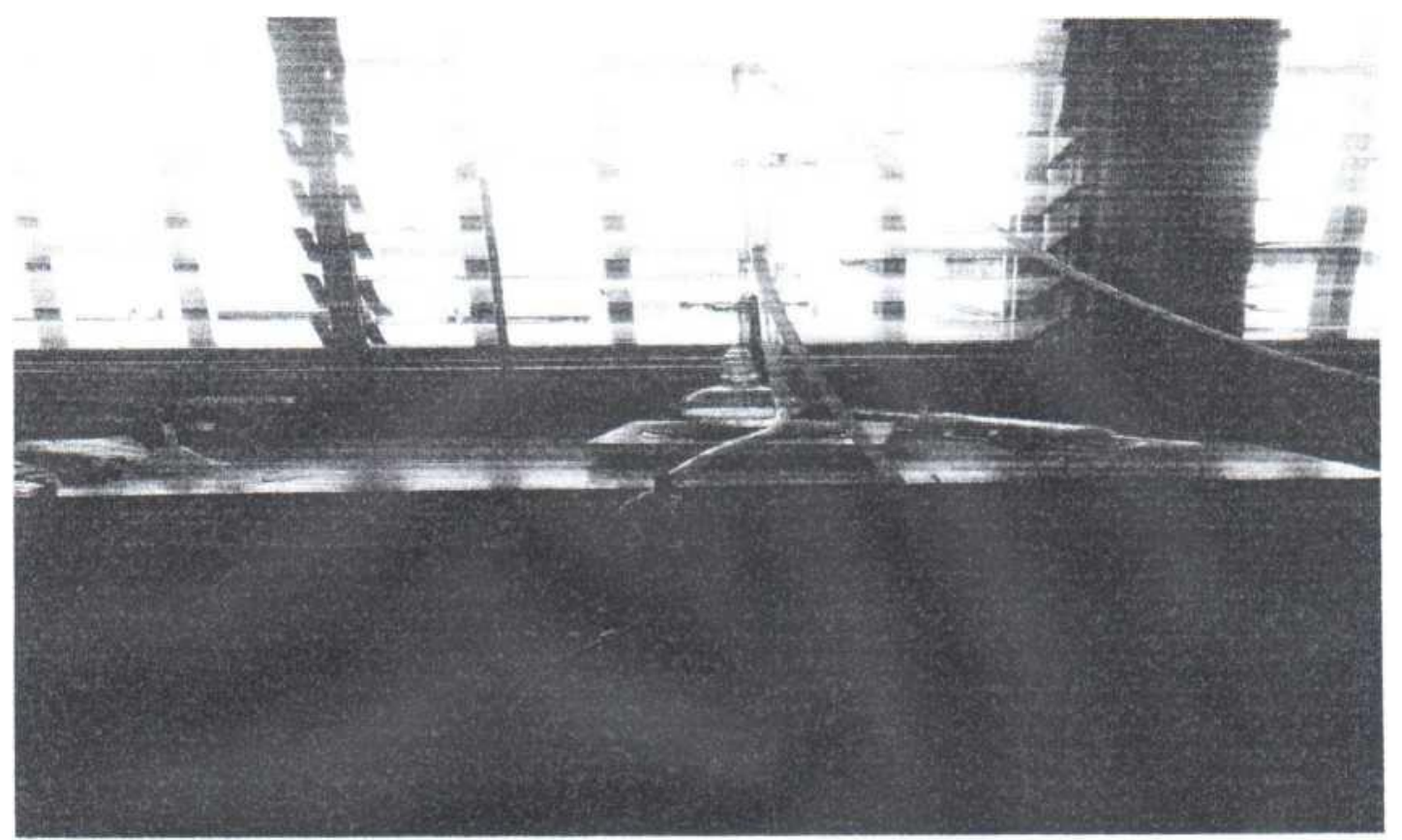

Figure 3.2: Distillation Setup for Distilling the Extract from the Extraction Process 


\subsubsection{Determination of Free Fatty Acid (FFA)}

A free fatty acid analysis was carried out to determine the percentage of FFA in the bio-oil. A standard solution of potassium hydroxide was prepared $(1$ gram of $\mathrm{KOH}$ and dissolved in 1 litre of $\mathrm{H}_{2} 0$ ). 1 gram of the oil was dissolved in 10ml of isopropyl alcohol, 2 drops of phenolphthalein indicator was added; $1 \%$ wt. the standard solution of potassium hydroxide was added in drops to the oil isopropyl alcohol mixture through a graduated syringe and stirred until it turned pink, and stayed for 10 seconds. HCL was used for the titration and the amount consumed was recorded.

The reason for conducting a titration before the biodiesel reaction was to determine the quantity of the base needed to completely neutralize any free fatty acid present thus, ensuring a complete transesterification process.

\subsection{Production of Bio-Diesel from Bio-Oil}

The simplest method of producing biodiesel is by transesterification method. Transesterification is the process whereby glycerol is removed from the fatty acid esters or the reaction of a fat or oil with an alcohol to form ester and glycerol.

Transesterification of the bio-oil is carried out with lower molecular weight alcohol in the presence of a base or acid catalyst which is the determination of free fatty acid.

\subsubsection{Transesterification}

$200 \mathrm{ml}$ of methanol was measured into a beaker via a funnel, methanol absorbs moisture from the atmosphere; therefore, the container was kept air tight and at room temperature to avoid exposure 5.3gram of $\mathrm{KOH}$ was added to the methanol via a second funnel. The container was shaken for 15 minutes to ensure the dissolution of $\mathrm{KOH}$ (pellets) in the methanol. 1 litre of the bio oil was preheated to $55^{\circ} \mathrm{C}$ in a water bath and poured carefully into a 2 litre container (blender). The prepared potassium methanoxide was measured into the preheated oil. The mixture was well mixed for a period of 1 hour at a constant temperature of $55^{\circ} \mathrm{C}$ (with the aid of a thermostatic bath) to achieve a state of homogeneity. The mixture (homogenous) was allowed to settle for 24 hours to achieve complete gravity separation with the darker-colored, denser by-product, glycerin settled at the bottom. The top light-colored liquid biodiesel was decanted off carefully into another container, leaving the glycerin at the bottom. The biodiesel was warmed to evaporate the molecules of water present and then stored. 


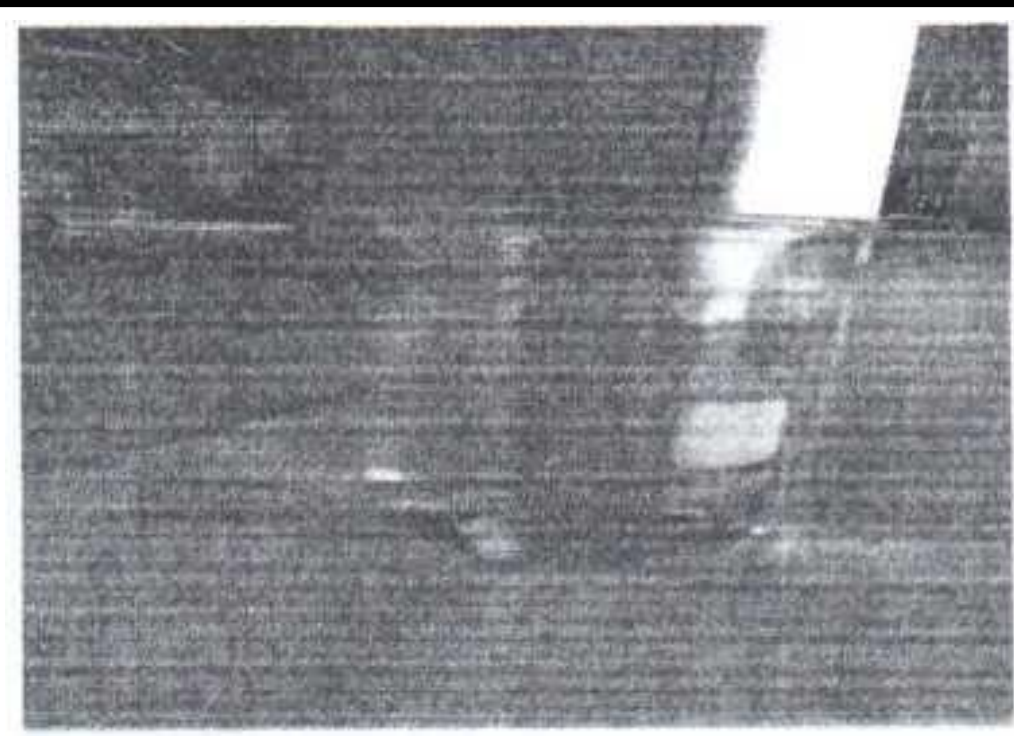

Figure 3.3: Biodiesel produced from corn cob oil (bio-oil)

\subsection{Characterization of Biodiesel}

The biodiesel produced was characterized by determining the following physio/chemical properties.
- Density
- $\quad$ Flash point
- $\quad$ Refractive index
- Viscosity
- $\quad$ Cloud point
- $\mathrm{pH}$
- $\quad$ Pour point

\subsubsection{Determination of Density}

Density is determined by weighing the empty pycnometer, then filling the pycnometer with biodiesel and weighed, all the necessary readings were taken and the density of the substance was calculated using the formula.

$\mathrm{D}=M / V$

Where: $\quad M=$ Mass of biodiesel

$\mathrm{V}=$ Volume of biodiesel 


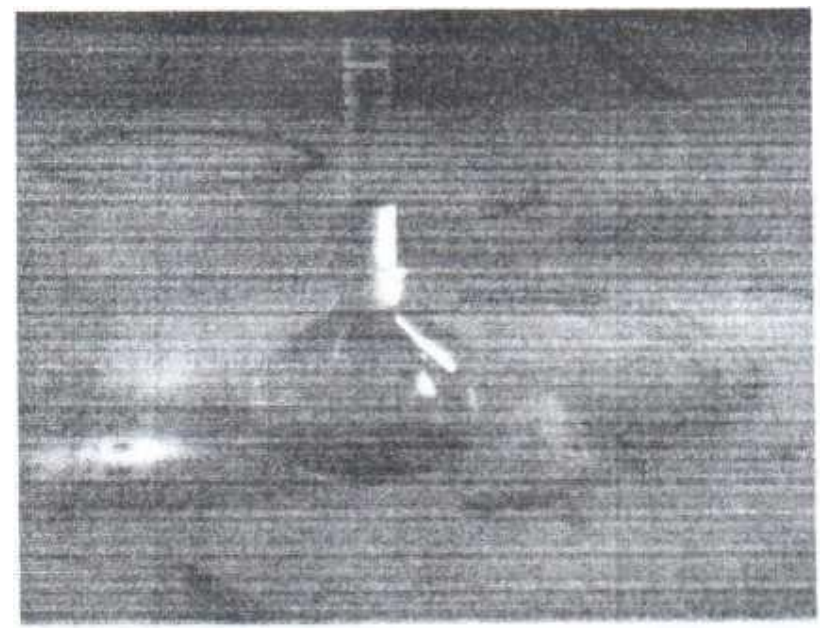

Figure 3.4: Pycnometer

\subsubsection{Determination of Flash Point}

The Flash point was determined using the pensky marten's flash point apparatus with a stirrer. The flash point cup was filled with biodiesel and was heated in the pensky marten's flash point apparatus. It has a point where you put a thermometer, the temperature at which vapor was reacting with the atmosphere the flame was ignited. The temperature reading was taken.

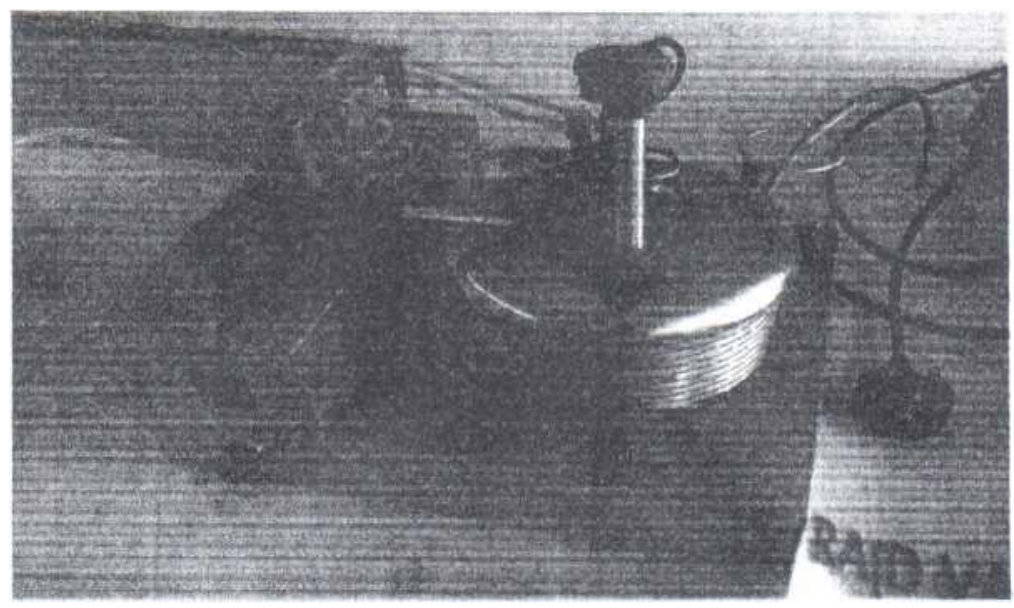

Figure 3.5: Pensky Marten's Flash Point Apparatus

\subsubsection{Determination of Refractive Index}

The refractive index is used for identification and establishment of purity of the oil. It is temperature dependent and measured at $25^{\circ} \mathrm{C}$. The hinge and the prism surfaces of the instrument were carefully cleaned with acetone. A drop of the biodiesel was dropped on the surface of the prism and was clamped. The biodiesel was observed through the telescope and the control knob adjusted so that coincidence of the dark parts was located in the wire, the 
refractive index is read directly from a scale which was observed through the second telescope. After the determination, the prism was wiped with tissue moisten with acetone.

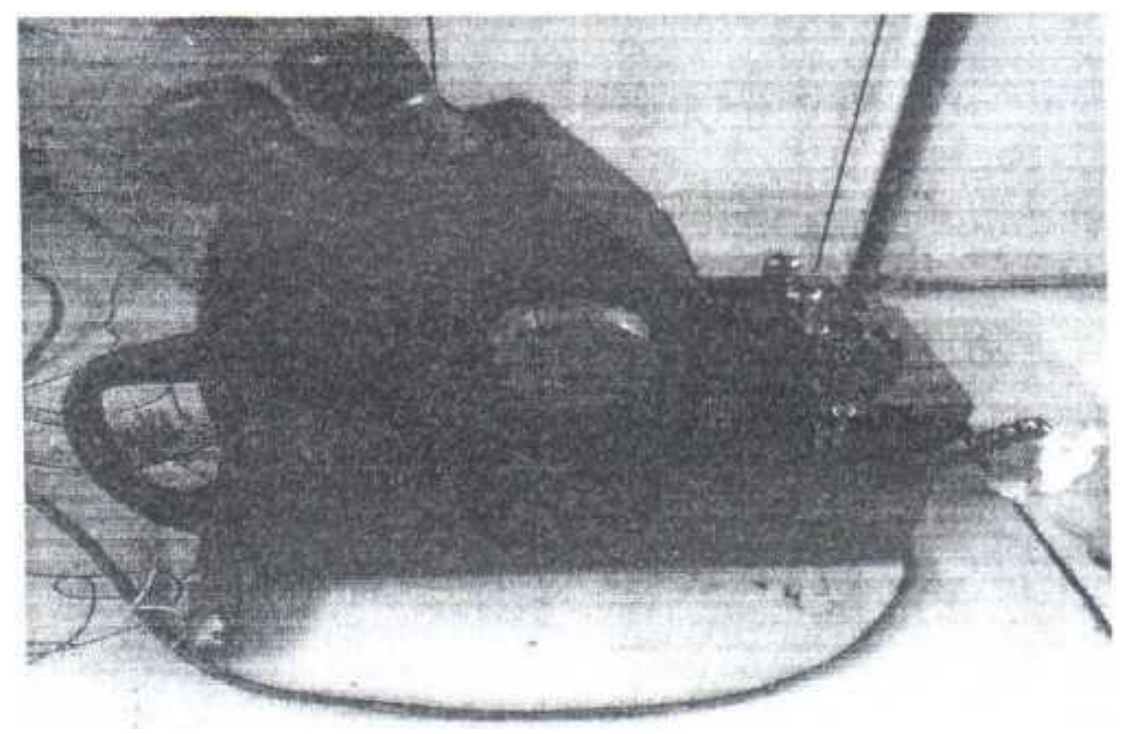

Figure 3.6: Refractometer

\subsubsection{Determination of Viscosity}

The viscosity of the substance was determined using a viscometer, the viscometer has low and upper levels were reading is taken. The capillary viscometer was filled with biodiesel; Viscometer filler or sucker was fixed to the mouth of the tube and then pumped till the fluid passes the upper level of the tube. A stop watch was started simultaneously as the biodiesel moves down till it gets to the lower tube; the value of time taken was multiplied by 0.01126 .

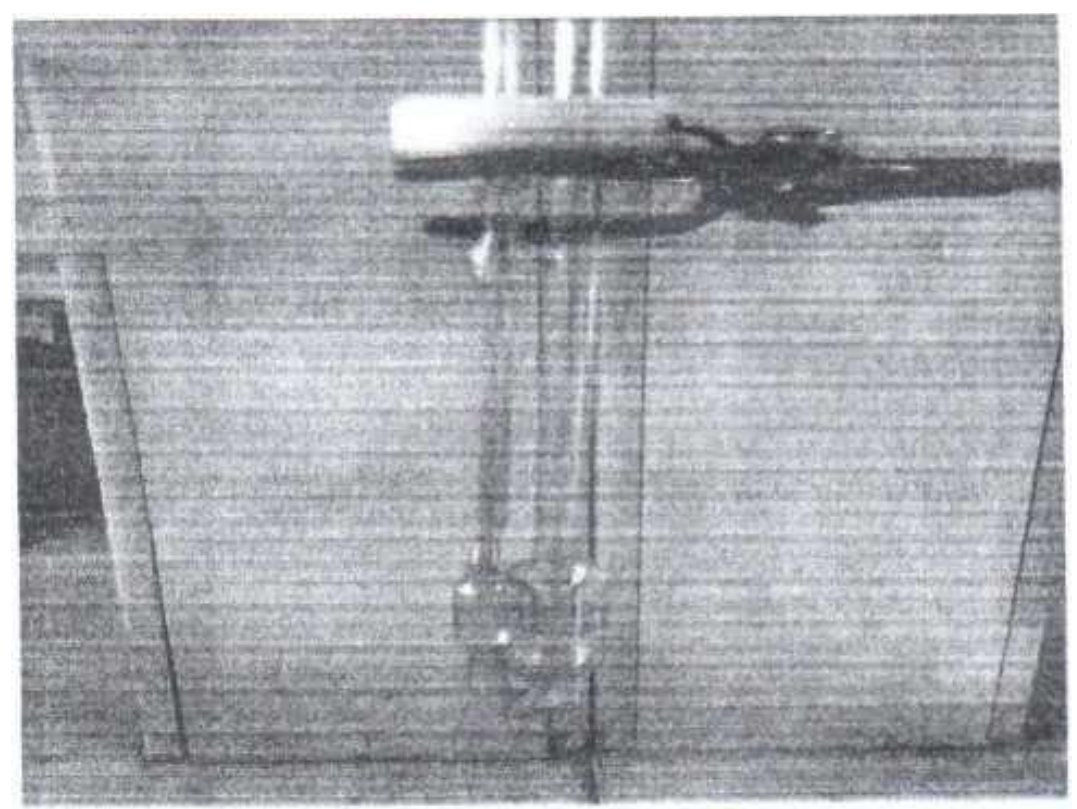

Figure 3.7: Viscometer 


\subsubsection{Determination of Cloud Point}

Cloud point is the temperature at which biowax crystal begin to form in the biodiesel. The biodiesel was poured in the test tube after which the test tube was inserted in the chamber of the air cooler machine then the machine was turned on. At intervals of $2^{\circ} \mathrm{F}$ the cloud point was checked for and reading was taken.

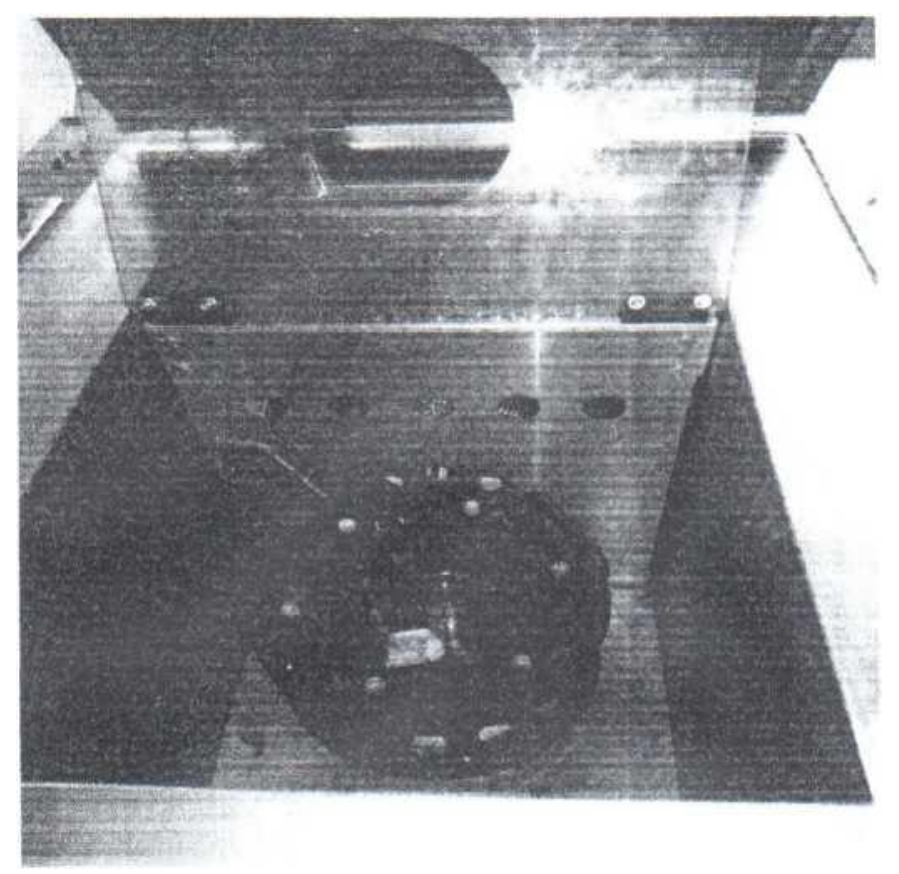

Figure 3.8: Cloud Point Determination Apparatus

\subsubsection{Determination of Pour Point}

This pour point is the temperature at which petroleum product begin to flow. The biodiesel was poured in the test tube after which the test tube was inserted in the chamber of the air cooler machine then the machine was turned on. At intervals of $3^{\circ} \mathrm{F}$ the cloud point was checked for and reading was taken. 


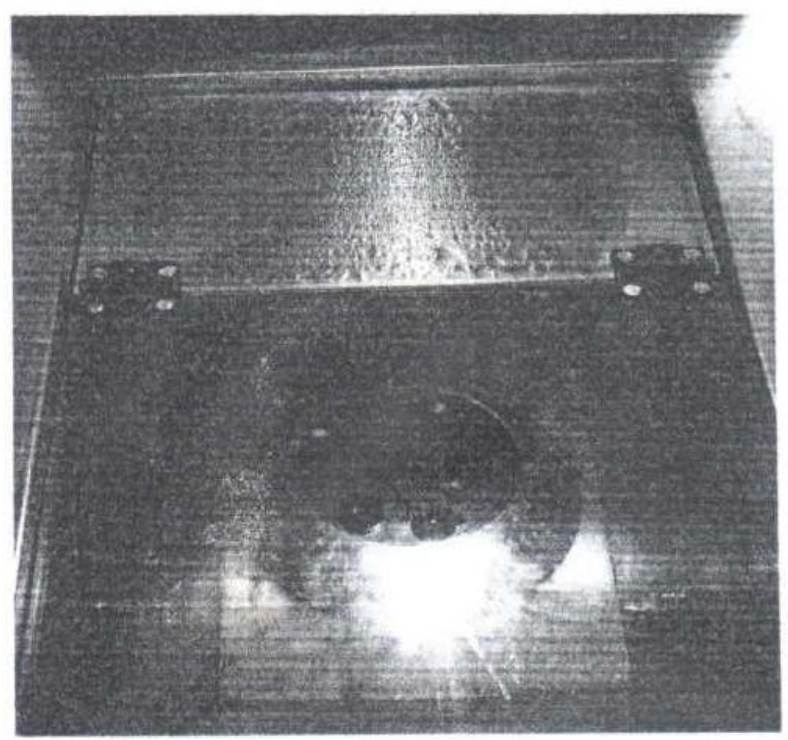

Figure 3.9: Pour Point Determination Apparatus

\subsubsection{Determination of $\mathbf{p H}$}

The point tester of the $\mathrm{pH}$ meter was inserted inside the beaker containing the biodiesel and then the reading was taken.

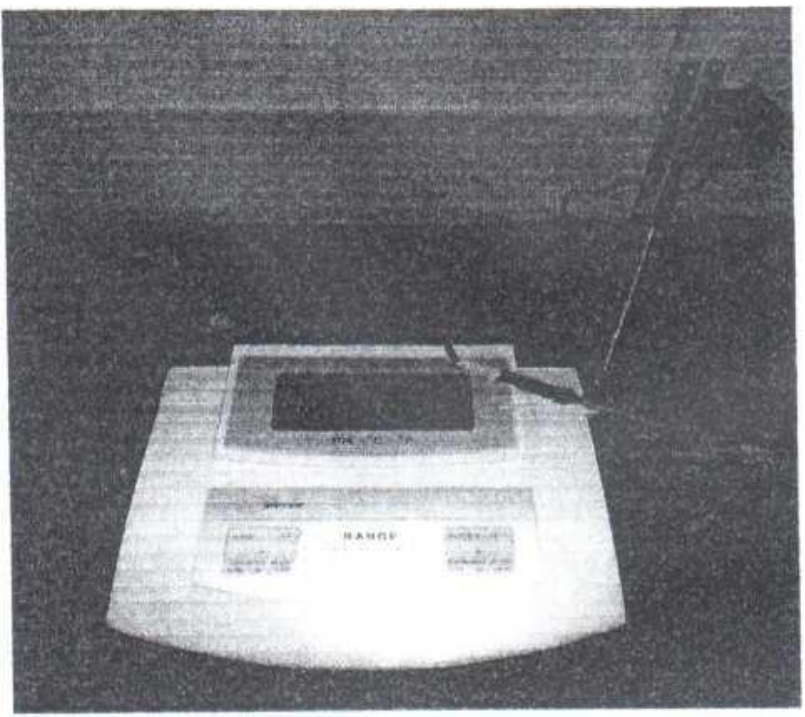

Figure 3 10: pH Determination Apparatus

\section{RESULT AND DISCUSSION}

The results of the characterization of the produced biodiesel were compared with that of a standard biodiesel to ascertain if it meets or exceeds standard requirements. 
Table 4.1: Comparing the Properties of Biodiesel from Waste Corn Cob Oil with Standard Biodiesel (DIN51606).

\begin{tabular}{|c|c|c|c|c|}
\hline Parameter & Unit & $\begin{array}{l}\text { Lab Experimental } \\
\text { values }\end{array}$ & $\begin{array}{l}\text { Biodiesel Value } \\
\text { (DIN 51606) }\end{array}$ & Difference \\
\hline $\begin{array}{l}\text { Kinematic } \\
\text { viscosity }\end{array}$ & $\mathrm{mm}^{2} / \mathrm{s}$ & 3.084 & $3.5-5.0$ & 2.9 \\
\hline Flash point & ${ }^{0} \mathrm{C}$ & 142 & $>110$ & 0 \\
\hline Cloud point & ${ }^{0} \mathrm{C}$ & $<-32$ & - & - \\
\hline Pour point & ${ }^{0} \mathrm{C}$ & $-52^{0}$ & - & - \\
\hline $\mathrm{pH}$ & & 9 & $7-9$ & 0 \\
\hline Density & $\mathrm{g} / \mathrm{cm}^{3}$ & 0.897 & 0.86-09 & 0.1 \\
\hline Odor & & Agreeable & $\begin{array}{l}\text { Depend on the } \\
\text { feedstock }\end{array}$ & - \\
\hline Color & - & Dark Amber-yellow & Amber-yellow & - \\
\hline $\begin{array}{l}\text { Refractive } \\
\text { index }\end{array}$ & & 1.454 & $140-1.477$ & 0 \\
\hline Sulphur & $\%$ mass & No sulphur content & $<0.01$ & - \\
\hline
\end{tabular}

Table 41 above shows the values of physiochemical parameters of biodiesel produced from lab compared to standard Biodiesel values (DINI5606). It can be seen from the table that the values of biodiesel produced from the lab compare favorably with those of the standard biodiesel (DIN15606). From the analysis the biodiesel obtained gave a pH 9 which is alkaline in nature. A value of 1454 brix was obtained as the refractive index The refractive index falls within the standard range (1 40-1.47). The density and viscosity of the biodiesel obtained is 0 $897 \mathrm{~g} / \mathrm{cm}^{3}$ and $3.084 \mathrm{~mm}^{2} / \mathrm{s}$ respectively and these values are in line with the standard value which is $3.5-5.0 \mathrm{~mm}^{2} / \mathrm{s}$ for viscosity and $0.86-0.9 \mathrm{~g} / \mathrm{cm}^{3}$ for density.

\subsection{Fuel Analysis}

Biodiesel properties from com cob oil produced in the lab in comparison with biodiesel produced in Gas-station and Diesel fuel; density, viscosity, flash point, cloud point.

A reliable operation of combustion engines is only possible when important characteristic of the fuel are defined These properties have to fulfill certain limiting values, otherwise guaranty and warranty agreement for proper engine operation or the conformity with relevant emission and regulations cannot be given. The specification of fuel quality by the use of consistent parameters and testing methods also enables fuel improvement.

\subsection{Technical Details and Standards of Diesel and Biodiesel}

There are three existing specification standards for diesel and biodiesel fuels (EN590, DIN51606 \& EN14214).

EN590: Describes the physical properties that all Diesel fuel must meet if it is to be sold in European Union (UN).

DIN 51606: is a German Standard for biodiesel, is considered to be the highest standard currently existing and is regarded by almost all vehicle manufacturers as evidence of compliance with the strictest standard for diesel fuels. Most biodiesel produced commercially meets or exceeds this standard. 
EN14214: is the standard for biodiesel now having recently been finalized by the European standard organization it is broadly based on DIN 51606.

Density: experiment result of density of biodiesel produced in lab at $30^{\circ} \mathrm{C}$ comparison with the density of biodiesel produced in a Gas Station (standard) Diesel fuel and corn cob oil.

Table 4.2: Density Measurement for corn cob Oil, Biodiesels and Diesel fuel

\begin{tabular}{ll}
\hline Fuel type & Density $\mathbf{g} / \mathbf{c m}^{\mathbf{3}}$ \\
\hline Corn cob oil & 45 \\
Biodiesel (lab) & 0.897 \\
Biodiesel (Gas station) & 0.887 \\
Diesel & 0825 \\
\hline
\end{tabular}

From the table, diesel fuel is seen to have the lowest density, followed by the biodiesel produced in the Gas station and lab respectively, the com cob oil has the highest density while the biodiesel produced in lab at $30^{\circ} \mathrm{C}$ falls within the limit specified by various international standards for biodiesel measure at $15^{\circ} \mathrm{C}$. German biodiesel standard (DIN 51606) ranges from 0.875-0,9. European standard ranges from 0.86-0.9 from the result of this Research, the density of the biodiesel produced from waste corn cob oil is in agreement with the above mentioned standard.

Viscosity: Experimental Result of Viscosity for the waste corn cob oil, two types of biodiesel and diesel fuel.

Table 4.3: Viscosity measurement for corn cob Oil, Biodiesels and Diesel fuel

\begin{tabular}{ll}
\hline Fuel type & Viscosity $\left(\mathbf{m m}^{\mathbf{2}} / \mathbf{s}\right)$ \\
\hline Com cob oil & 20.22 \\
Biodiesel (lab) & 3.084 \\
Biodiesel (gas station) & 4454 \\
Diesel & 3.095 \\
\hline
\end{tabular}

From the table, the biodiesel produced in lab has the lowest value, while com cob oil has highest, viscosity is very important in the production of biodiesel and diesel, higher viscosity interferes with injector operation resulting in poor atomization of the fuel. The viscosity of the biodiesel produced in lab falls within the range set by the international standard (DIN51606. EN14214) but it is slightly below the value of the fossil diesel.

Flash Point: The table shows the different flash points of different fuel.

Table 4.4: Flash Point measurement for Corn Cob Oil, Biodiesels and Diesel Fuel

\begin{tabular}{ll}
\hline Fuel type & Flash point ${ }^{0} \mathrm{C}$ \\
\hline Corn cob oil (waste) & $327^{0} \mathrm{C}\left(621^{0} \mathrm{~F}\right)$ \\
Biodiesel (Lab) & $142^{0} \mathrm{C}\left(288^{0} \mathrm{~F}\right)$ \\
Biodiesel (Gas Station) & $130^{0} \mathrm{C}\left(266^{0} \mathrm{~F}\right)$ \\
Diesel & $52^{\circ} \mathrm{C}\left(126^{0} \mathrm{~F}\right)$ \\
\hline
\end{tabular}

From the flash point of biodiesel produced from the lab is $142^{\circ} \mathrm{C}$, the flash point decreases after transesterification which shows that the volatile characteristic had improved and is safe and this is also in agreement with European standard which must be $>110$. 
Cloud Pour/Pour Point: cloud point and pour point are criterion used for temperature performance of fuel. The cloud and pour points of the analyzed biodiesel gives less than $32^{\circ} \mathrm{C}$ and $-52^{\circ} \mathrm{C}$ respectively

Refractive Index: In some cases, the refractive index is not always given consideration. The refractive index in this research gives 1454 brix

Table 4.5: Some Properties of Diesel and Biodiesel Standards (http14)

\begin{tabular}{lcccc}
\hline Properties & Unit & Derv(EN590) & Biodiesel(DIN51606 & Biodiesel(EN14214) \\
\hline Density & ${\mathrm{g} / \mathrm{cm}^{3}}^{2}$ & $0.82-0.86$ & $0.875-0.9$ & $0.86-0.9$ \\
Viscosity & $\mathrm{mm}^{2} / \mathrm{s}$ & $2.0-4.5$ & $3.5-5.0$ & $3.5-5.0$ \\
Flash point & ${ }^{0} \mathrm{C}$ & $>55$ & $>110$ & $>101 \mathrm{H}$ \\
Sulphur & $\%$ mass & 0.20 & $<0.01$ & $<0.01$ \\
Refractive & Brix & - & $1.40-1.477$ & $140-1.477$ \\
index & & & $7-9$ & $7-9$ \\
pH & & - & & \\
\hline
\end{tabular}

The table above shows the standard value for the parameters a biodiesel and diesel must meet or exceed before it can be sold in the European Union.

\subsection{Conclusions}

\section{CONCLUSIONS AND RECOMMENDATIONS}

The production of biodiesel from an environmentally polluting material, corn cob has been established through extraction and transesterification process, and an environmentally friendly fuel was obtained.

A total mass of $20.19 \mathrm{wt} \%$ of bio-oil was obtained and transesterified to produce biodiesel which is carbon neutral, rapidly biodegradable and completely non-toxic.

It has become more attractive recently because of its environmental benefits and the fact that it is made from renewable resources; Biodiesel is the best alternative for fossil fuel

The viscosity, density, flash point of biodiesel produced after transesterification in this research is in line with the standard set by international bodies. Hence utilization of these waste materials which is the used corn cob does not only manage the environment but is also a means of providing an alternative fuel.

\section{$5.2 \quad$ Recommendation}

It is recommended to rectify the condensation unit designing a two condenser system with optimized temperature in order to improve the quality of the bio-oil by removing the water and light volatile content in the liquid product.

Further research can be carried out on the production of biodiesel from other feedstock; the volume of waste corn cob is quite maximal. Government should give incentives to those who are willing to go into the production of biodiesel in a large scale as this may serve as an alternative fuel to fossil fuel. 


\section{REFERENCE}

ASTM (1979). Annual Book of ASTM standards, part 23. American society of testing materials Philadelphia P.A.

Bourne J. K. (2007). Green dreams. National Geographic. 212(4): 38-59.

Dahlberg, R.W., Winter, P. \& Dallas, D. (1948). The storage of corn cobs and other agricultural residues for industrial use. Agricultural engineering 29 (1): 11- 13.

Environmental protection Agency (2009). EPA proposes new regulations for the National Renewable fuel standard program for 2010 and Beyond. Available at http/www.epa.gov/oms/renewablefuels/42of09023.htm accessed June 1st 2010

Heck, (2004). Bio fuel positive and negative impact. www.cvberhd.org/qlvcer/biodiesel.htm

Kallyan, N. \& Vance, M. R. (2008). Densification characteristics of corn cobs. ASABE meeting presentation paper number 084267.

Morey, R. V., Thimsen, D.P., Lang, J. P. \&Hansern, D. J. (1984). A corn cob fueled drying system. Trans ASAE 27(2): 556 - 560.

NREL (2007). Theoretical ethanol yield calculator. Washington, DC: US Department of Energy. Available at www.eere.enerqv.qov/biomass/ethanolveildcalculator.html. accessed 1st June, 2010.

Perlack, R.D., Wright, L.L., Thrhollow, A.F., Graham, R. L., Stokes, B.J., Erbach, D. C. (2005). Biomass as feedstock for a Bioenergy and Bio products industry. The technical feasibility of a Billion Ton Annual Supply (oak ridge National Laboratory, oak Ridge, TN) ORNL/TM-2005/66.

Reeder, R. \& Li, Y. (2010). Determining location of cellulosic ethanol plants in Ohio, based on availability of crop residues, transactions of the ASAE 52(10; 313- 318.

Ruldof Diesel (1912). www.chemistrv.orq/portal/a/c/s/l/feature-tea.html.

www.anl.gov/pc/acsfuel/preDrint\%20archive/files/volumes/vol40-4pdf.

www.arborbiofuelcompanv.com/transesterification-101 htm.

www.cvberlipid.org/glvcer/biodiesel.htm

www.esru.strath.ac.uk/Eande/web-sites/02-03/biofuels/what-biodieselhtm 